Ольга Хардікова,

Воєнно-дипломатична академія імені Свгенія Березняка, м. Київ ORCID 0000-0002-1779-4412

DOI: $10.33099 / 2617-1775 / 2019-02 / 165-173$

\title{
ФОРМУВАННЯ ТЕМАТИЧНИХ ВОКАБУЛЯРІВ У ОСВІТНЬОМУ ПРОЦЕСІ 3 УРАХУВАННЯМ НЕОЛОГІЗМІВ І СУЧАСНИХ ТЕНДЕНЦІЙ РОЗВИТКУ АНГЛІЙСЬКОЇ МОВИ
}

У статті розглянуто сутність поняття «мовна компресія», «неологізм», досліджено механізми формування неологізмів в англійській мові та окреслено значення мовної компресії як механізму збагачення англійської мови неологізмами, проаналізовано особливості формування загальномовних лексичних неологізмів за допомогою мовної компресії яку потрібно враховувати під час проведення занять у вищих закладах вищої освіти.

Ключові слова: мовна компресія; неологізм; елізія; універбачія. лексичний апарат; фразеологізми.

Постановка проблеми. У часи сьогодення мова знаходиться в постійній зміні і динаміці, причому самим рухомим його компонентом є словниковий склад. 3 одного боку спостерігається тенденція до спрощення мови, уніфікації, а $з$ іншого до ііі ускладнення, інтелектуалізації. Змінюються значення слів, деякі слова вимирають, з'являються нові. Склад основних граматичних форм мови змінюється поступово та за дуже довгий проміжок часу. Лексика як найбільш рухливий пласт мови, найбільш чутливо реагує на всі зміни в соціальній, культурній та інших сферах життя, адже саме слово є «дзеркалом життя».

Процес оновлень в лексиці відбувається постійно, але є часи, коли він особливо інтенсивний. Таким періодом в історії лексики стала друга половина XX століття, коли в Європі відбулися радикальні зміни - змінилися політичні умови життя носіїв мови, спостерігаються значні успіхи економіки i вдосконалення соціальної системи. Все це, в поєднанні із загальними для світової культури технічними та матеріальними нововведеннями, не могло не позначитися на кількісному зростанні вокабуляра сучасної англійської мови, на формуванні окремих його ділянок.

Словниковий склад англійської мови безперервно розвивається. Особливо схильні до змін ті ділянки лексики, які не входять до стійкої частини словника, яка містить загальновживані слова. Змінюються значення слів, змінюється $\mathrm{i}$ склад словника: одні слова зникають, інші утворюються, причому останніх значно більше, ніж перших.

У процесі викладання англійської мови слухачам у закладах вищої освіти (3ВО) набуває важливості усвоєння сучасного, не застарілого, а значить неефективного, вокабуляру за фаховим спрямуванням.

Аналіз останніх досліджень та публікацій. Мовна компресія як напрям дослідження зявився у II-ї половини XX ст. Одним з перших проблематику мовної компресії окреслів чеський мовознавець В. Матезіус [9]. Актуальними в 
цьому напрямі стали роботи таких науковців, як І. Арнольд [1], Ю. Бернадська [2], Ю. Бец [3], О. Бігич [4], Н. Валгіна [5], Б. Дюндик [6], М. Калениченко [7], Я. Конопацька [8], Л. Мурзіна [10], С. Ординської [11], Т. Пакулова [12], О. Панченко [13], Л. Сутуліна [14], А. Чудинов [15] та ін.

Незважаючи на численні праці із цієї тематики, багато питань залишаються не дослідженими: дослідники не можуть дійти одностайності щодо ролі мовної компресії у формуванні неологізмів. Актуальність статті обумовлена безперервним поповненням англійської лексики у зв’язку 3 мінливим оточенням, а також, все більшим поширенням англійської мови у світі і необхідністю пристосування лексичного апарату англійської мови до різних етно-культурних середовищ, потребою врахування змін у сучасному англійському вокабулярі науково-педагогічними працівниками під час підготовки і проведення занять.

Мета статті: дослідити тенденції розвитку сучасної англійської мови, проаналізувати особливості формування загальномовних лексичних неологізмів за допомогою мовної компресії.

Методи дослідження. Комплексний науковий аналіз проблеми дослідження; систематизація та узагальнення інформації, отриманої з наукових і методичних джерел; методи порівняння, класифікації, абстрагування, індукції та дедукції.

Виклад основного матеріалу. Життя не стоїть на місці: навколо нас постійно відбуваються різні зміни, розвивається наука, з'являються нові ідеї, нові поняття, нові предмети, нові технічні пристрої. Мова - жива динамічна система, яка реагує на будь-які соціальні зміни. I кожне нове явище, новий процес вимагають своєї назви - нового слова. Наповнення лексики новими словами - процес безперервний.

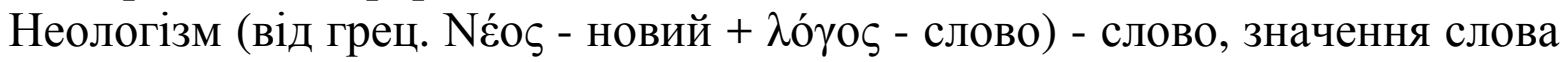
або словосполучення, що недавно з'явилося в мові (новостворене, було відсутнє раніше). Поняття неологізму відносне: слово вважається неологізмом, допоки відчувають в ньому ефект новизни і свіжості. 3 плином певного періоду часу неологізми можуть бути повністю освоєні мовою i перестають бути неологізмами, стають звичайними словами основного запасу мови.

В 60-і pp. ХХ ст. в зв'язку з розвитком космонавтики з'явилося багато нових слів, пов'язаних 3 космосом: астронавт, космонавт, космодром, ракетодром, місяцехід і ін. Звичайно, в даний час їх уже не можна вважати неологізмами, оскільки вони давно увійшли в мову, широко в ньому вживаються.

Зараз у зв'язку з активним розвитком науки і техніки ми часто чуємо такі слова, як бонус, дедлайн, тренд, креатив, мерчендайзер, копірайтер, супервайзер, коуч, лікомбез (ліквідація комп'ютерної безграмотності), кварки (елементарні частинки), хромодинамика (розділ фізики). Це приклади неологізмів теперішнього часу. Неологізми, які 3'являються на периферії мовної системи якийсь час перебувають у розпорядженні цієї периферії і лише 
поступово, не всі, а найбільш відповідні структурним вимогам слова мови, переміщаються до центру мовної системи, до основного словникового фонду.

Як відомо, у мові існують загальномовні неологізми (лексичні i семантичні) та індівідуально-стилістичні (індивідуально-авторські). Мовна компресія - це специфічне лінгвістичне явище, яке спостерігається, коли $\epsilon$ можливість скорочення деякої частини тексту без істотного збитку для його змісту.

Хоча термін "компресія" 3'явився в лінгвістиці лише в середині ХХ століття, саме поняття компресії до сих пір не отримало однозначного тлумачення у лінгвістів. В цілому в роботах різних авторів можна виявити близько двадцяти відмінних одне від одного визначень явища компресії. Крім цього виділяють безліч різних тлумачень видів компресії на різних рівнях: близько десяти визначень еліпсису, кілька визначень скорочення, стиснення, редукції, а також визначення таких явищ, як заміщення, суміщення, згортання, тощо.

Огляд сучасної лінгвістичної літератури свідчить про те, що в лінгвістиці тексту існують два підходи до тлумачення явища компресії - в "широкому" та "вузькому" сенсі.

Компресія в широкому розумінні $є$ однією 3 головних тенденцій у функціонуванні мови, що діє по всій сфері функціонування, яка проявляється по-різному, більш-менш інтенсивно, за різними конкретно-комунікативним сферам, відповідністю яких в мові є функціональні стилі.

Під компресією у вузькому сенсі розуміють набір тих конкретних засобів, які служать цілям реалізації компресії в широкому сенсі на всіх мовних рівнях.

Відповідно до думки багатьох лінгвістів, розвиток мови визначається дією двох тенденцій - до розширення і компресії. У процесі спілкування співрозмовник керується двома основними прагненнями: прагненням до «оптимізації мовного коду», що, безумовно, пов'язано 3 розширенням структури, 3 одного боку, а 3 іншого - прагненням до «економії зусиль». Особливо це проявляється в розмовній мові, що має такі особливості:

1) участь співрозмовника;

2) ситуативність спілкування;

3) спонтанність мовлення;

4) емоційність.

Відповідно до структурної характеристики мови вищеописані риси непідготовленої усної комунікації створюють в промові переплетіння двох протилежних тенденцій - мовної економії та мовної надмірності [14].

Як правило, тенденція до економії тягне за собою структурну неповноту висловлювання, що, однак, не перешкоджає розумінню співрозмовниками один одного. Це явище в процесі створення неологізмів називають елізією.

Елізія (від лат. elisio - виштовхування, вижимання) у лінгвістиці випадання звуку (голосна, приголосна або склад) у слові або фразі з метою полегшення вимови для мовця. Іноді звуки можуть бути опущені 3 метою поліпшення благозвучності. Як правило елізія несумисна, але може бути 
зумисною. Суб'єктивно елізія сприймається як невиразна вимова або як пропущений звук.

Приклади осмисленої елізії можна знайти в давньоримській поезї, де вона використовувалася як стилістичний засіб. У деяких випадках, наприклад коли одне слово закінчується на голосну, а наступне починається також 3 голосної, слова можуть об'єднуватися. До елізії часто вдавався Катулл. Наприклад, перший рядок з Catullus 3: Lugete, O Veneres Cupidinesque читається як Lugeto Veneres Cupidinesque.

Якщо скорочена в результаті елізії форма вживається досить часто, вона може стати заміною для первинної (повної) форми. В англійській мові це явище називається стягненням (англ. contraction), наприклад can't від cannot. Стягнення відрізняється від елізії тим, що стягнені форми, на відміну від елізії, морфологічно описані.

У розмовній мові частіше за все відбувається елізія голосних, що часто супроводжує асиміляцію та елізію приголосних. У процесі мови явище елізії практично непомітне для слухача, якого цікавить інформація, що повідомляється тим, хто говорить, а не точність вимови. Таким чином, можна розглядати цей процес як спосіб економії мовних зусиль 3 боку того, хто говорить.

Типовою для англійської мови є елізія нейтрального звуку (так званого schwa sound) y ненаголошеному складі багатоскладових слів, наприклад: diff(e)rent, ev(e)ning, ev(e)ry, veg(e)table, int(e)resting. У розмовній мові практично усі ненаголошені склади вимовляються 3 нейтральним звуком.

У швидкій мові елізія трапляється у деяких двоскладових словах, які скорочуються до одного складу. Наприклад: c(o)rrect, p(a)rade, p(o)lice, $\mathrm{s}(\mathrm{u})$ ppose.

До цього ж типу елізіі можна віднести і випадіння ненаголошеного початкового голосного звуку або складу у розмовній мові, наприклад: 'cause, 'bout, 'round.

Тепер звернемося до типових тенденцій модифікацій приголосних. Елізія приголосних трапляється не рідше, ніж елізія голосних. Цей процес відбувається, наприклад, у останньому складі, коли звук знаходиться між двома приголосними. У подібних випадках елізії часто зазнають звуки [t] та [d]. Наприклад: eas $(t)$ side, blin(d) man, wil(d) boar, res(t)less, win(d)mill.

Випадіння [t] можна спостерігати у словах, де [nt] знаходиться між двома голосними або перед [1]: win(t)er, en(t)er, man(t)le.

Приголосний [v] у of зазнає елізії (скорочується до нейтрального звуку) перед словами, що починаються з приголосного: lots of [ə] money, waste of [ə] time. У займенникових формах у зв’язній мові відбувається випадіння початкового [h]: ask (h)er, help (h)im.

Таким чином, елізія - порушенням фонетичної норми, що виникає у мовному потоці, і спостерігається у сучасній англійській мові.

Ще однією характерною особливістю англійської мови $є$ фонетична редукція допоміжних та модальних дієслів: it's, it isn't, I don't, you can't і т.д. У 
тих випадках, коли усічені форми дієслова 'have' I've та he's виявляються недостатніми для передачі значення 'мати', 'володіти', використовується конструкція з дієсловом 'get': I've got, he's got.

$\mathrm{Ti}$, хто говорять англійською мовою, мають тенденцію нечітко вимовляти такі слова, що $є$ часто вживаними та добре відомими, особливо назви місцевості. Так, австралійці скажуть вам, що вони з 'Stralia' (Australia), жителі міста Торонто - 3 'Tronna'(Toronto), а ті, що проживають у американському штаті Айова - 3 'Iwa' (Iowa).

Усі зазначені вище фонетичні процеси є природними для носіїв мови, але можуть викликати труднощі у сприйнятті на слух мови тими, хто вивчає іiї як іноземну, а отже опанування ними не повинно залишатися поза увагою у процесі оволодіння англійською мовою.

Компресію розглядають як вторинний процес і результат, які сприяють доведенню розгорнутої конструкції до згорнутої зі збереженням об'єму інформації, що передається. Саме в результаті багатократного повторення такої лексичної конструкції виникає явище утворення в мові неологізмів.

Широкий спектр засобів для наповнення мови неологізмами пропонує компресія на лексичному рівні. У іiі арсеналі - різні види універбації, запозичення, кальки, фразеологізми, просторічні слова, слова-терміни, професіоналізмі, історизми, архаїзми, діалектизми, жаргонізми. Кожен із цих засобів має компресувальний потенціал.

Універба́ція (з латин. unum verbum - «одне слово») - спосіб утворення слова на основі словосполучення, при якому в похідне слово входить основа лише одного з членів словосполучення, тобто по формі похідне співвідносне лише з одним словом, а за змістом - 3 цілим словосполученням. В лінгвістичній літературі цей спосіб творення іменується по-різному: включення, стягнення, семантична конденсація, еліпсис, згортання найменувань i, найчастіше, універбація. Під час різних видів універбації семантика словосполучення конденсується в одному слові, у такий спосіб скорочують формальну структуру закладеної інформації: laptop (англ. lap = коліна сидячої людини, top = верх). Англійська мова, як і більшість інших сучасних романо-германських мов не $\epsilon$ виключенням з загального процесу конденсації мовленнєвих зусиль і мовних засобів. Наприклад, тут зустрічаємо

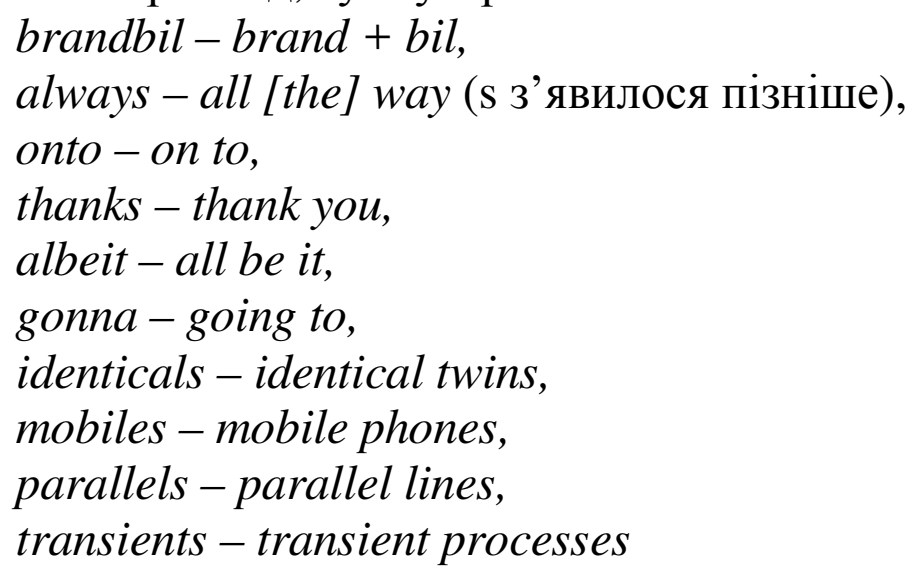


Як відомо, пришвидшення темпу життя, необхідність в масовій номінації зумовлює утворення в мовленні й мові новітніх назв тих чи інших процесів та предметів, які вже означено відповідними визначеннями[14]. 3 метою сповіщення про щось за допомогою мови, необхідно знайти назви об'єктам, які нас цікавлять, і синтезувати ці назви. Зокрема й зміни самої дійсності потребують фіксації в мовленні й мові шляхом нових визначень. Зміни емоційного фону також вимагають нових засобів опису, які були б більш ефективними, ніж звичайні. Цю потребу в нових найменуваннях мова може задовольняти різними шляхами, спільною ознакою яких є закономірний зв'язок 3 тим, що вже створено мовою, що виявилося в ній як спроможне бути основою й вихідною точкою для нового.

Висновки та перспективи подальших досліджень. Таким чином, основне джерело неологізмів в сучасній англійській мові - мовна компресія. Мовна компресія як механізм утворення неологізмів використовує два основні механізми - елізію і універбацію. Процес утворення неологізмів за допомогою універбації та елізії як основних механізмів мовної компресії $є$ складовою загального процесу задоволення потреби суспільства наповнення мови новими лексичними одиницями. Під час підготовки i проведення занять науковопедагогічним працівникам потрібно враховувати зміни у сучасному англійському вокабулярі.

У подальшому продовжити дослідження складових і видів універбації та елізії як тенденцій до наповнення англійської мови неологізмами. Створити словник неологізмів що з'явилися за останні 5 років для подальшого їх використання у фахової діяльності.

\section{ЛІТЕРАТУРА} $384 \mathrm{c}$.

1. Арнольд И. В. Стилистика. Современный английский язык. Москва, Наука, 2002.

2. Бернадская Ю. С. Основы рекламы Москва, Наука, 2008. 281 с.

3. Бец Ю. І. Особливості перекладу та транслювання у контексті сучасних лінгвістичних теорій. Іншомовна підготовка працівників правоохоронних органів і сектору безпеки: матеріали III Міжнародної наук.-практ. конф. (27 березня 2019 року). Київ, 2019. C.29- 31 .

4. Бігич О.Б. Технології формування методичної компетентності викладача іноземної мови. Вісник Київського Національного Лінгвістичного Університету. 2018. Вип. 28. С. 189 $-197$.

5. Валгина Н. С. Теория текста. Москва, Логос. 2003. 280 с.

6. Дюндик Б. П. Компрессия и некоторые вопросы перевода. Бизнес-образование и эффективное развитие экономики. Иркутск, 2007. С. 282 - 288.

7. Калениченко М. М. Способи та специфіка творення неологізмів у чеській мові. Іншомовна підготовка працівників правоохоронних органів і сектору безпеки: матеріали III Міжнародної наук.-практ. конф. (27 березня 2019 року). Київ, 2019. С. 65 - 68.

8. Конопацька Я.О. Особливості інтеграції нових лексичних одиниць у систему мови. Вісник Львівського університету. 2012. Вип. 19. С. 174 - 179.

9. Матезиус В. Избранные труды по языкознанию. Москва, Едиториал УРСС. 2003. $232 \mathrm{c}$.

10. Мурзин Л. Н. Компрессия и семантика языка. Семантика и производство лексических единиц (проблема деривации). Пермь, 1979. С. 36. 
11. Ордынская С. Н. Языковая компрессия: ее онтология, сущность и функции. III Международные Бодуэновские чтения: материалы конференции в 2 т. Казань, 2006. Т. 2. С. $12-13$.

12. Пакулова Т. В. Универбация в английском языке как одна из реализаций компрессии. Лінгвістичний вісник. 2016. Вип. 5. С. 57-62. URL: http://nbuv.gov.ua/UJRN/livis_2016_5_8. (дата звернення: 28.05.2019).

13. Панченко А. М., Смирнов И. П. Метафорические архетипы в русской средневековой словесности и поэзии начала XX века. Tpyды Oтдела древнерусской литературы. 1971. T. 26. URL: http://lib.pushkinskijdom.ru/Portals/3/PDF/ TODRL/ 26 tom/ Panchenko_Smirnov/pdf. (дата звернення: 27.05.2019).

14. Сутуліна Л. Г. Етапи дослідження метафоричних моделей. Філологічні науки: зб. метаріалів підсумк. наук. конференції студентів та викл. факультету. Дніпропетровськ, 2014. С. $403-405$.

15. Чудинов А. П. Политическая лингвистика. Москва, Наука, 2006. 256 с.

\section{REFERENCES}

1. Arnold Y. V. Stylystyka. Sovremennyy anhlyyskyy yazyk. Nauka. [Stylistics. Modern English. The science.] Moskva, 2002. 384 s.

2. Bernadskaya YU. S., Marochkyna S. S., Smotrova L. F. Osnovy reklamy. Nauka. [Basics of Advertising. The science.] Moskva, 2008. $281 \mathrm{~s}$.

3. Bets YU. I. Osoblyvosti perekladu ta translyuvannya u konteksti suchasnykh linhvistychnykh teoriy. Inshomovna pidhotovka pratsivnykiv pravookhoronnykh orhaniv ta sektoru bezpeky: [Features of translation and interpretation in the context of modern linguistic theories. Foreign language training for law enforcement officers and the security sector] materialy III mizhnar. nauk.-prakt. konf., m. Kyyiv, 27 bereznya. 2019r. [The materials of the third international science practical conference in Kyiv city, March 2019] Kyiv, 2019. S. 29-30.

4. Bihych O.B. Tekhnolohiyi formuvannya metodychnoyi kompetentnosti vykladacha inozemnoyi movy. Visnyk Kyyivskoho Natsionalnoho Linhvistychnoho Universytetu. Seriya Pedahohika ta psykholohiya. [Techniques of formation of methodical competence of an English teacher. Newsletter of Kyiv National National University. Pedagogy and Psychology seria.] 2018. Vyp. 28. S. $189-197$.

5. Valhyna N. S. Teoryya teksta. [Theory of Text] Lohos, Moskva, 2003. $280 \mathrm{s.}$

6. Dyundyk B. P. Kompressyya y nekotorye voprosy perevoda. Byznes-obrazovanye y éffektyvnoe razvytye ékonomyky. [Compression and some translation issues. Business education and effective development of the economy.] Yrkut.sk, 2007. S. 282-288.

7. Kalenychenko M. M. Sposoby ta spetsyfika tvorennya neolohizmiv u cheskiy movi. Inshomovna pidhotovka pratsivnykiv pravookhoronnykh orhaniv ta sektoru bezpeky: materialy III mizhnar. nauk.-prakt. konf., m. Kyiv, 27 bereznya. [Methods and specifics of creation of neologisms in Czech. The materials of the third international science practical conference in Kyiv city, March 2019] S. 65-67.

8. Konopatska YA.O. Osoblyvosti intehratsiyi novykh leksychnykh odynyts u systemu movy. [Features of the integration of new lexical units into the language system.] Visnyk Lvivskoho universytetu. 2012. Vyp. 19. S. 174-179.

9. Matezyus V. Yzbrannye trudy po yazykoznanyyu. [Selected Works on Linguistics.] Moskva, 2003. $232 \mathrm{~s}$.

10. Murzyn L. N. Kompressyya y semantyka yazyka. Semantyka y proyzvodstvo leksycheskykh edynyts (problema deryvatsyy). [Compression and language semantics. Semantics and production of lexical units (the problem of derivation).] Perm, 1979. S. 36.

11. Ordynskaya S. N. Yazykovaya kompressyya: ee ontolohyya, sushchnost y funktsyy. III Mezhdunarodnye Boduénovskye chtenyya : materyaly konferentsyy v 2 t. Kazan, [Language compression: its ontology, essence and functions. III International Boduenov readings: conference materials in 2 volumes. Kazan publishing] Yzd-vo Kazan. un-ta, 2006. T. 2. S. 12-13. 
12. Pakulova T. V. Unyverbatsyya $\mathrm{v}$ anhlyyskom yazyke kak odna yz realyzatsyy kompressyy.

[Univerbation in English as one of the realizations of compression.] Linhvistychnyy visnyk. 2016. Vyp. 5. S. 57-62. URL: http://nbuv.gov.ua/UJRN/livis_2016_5_8 (data zvernennya: 28.05.2019).

13. Panchenko A. M., Smyrnov Y. P. Metaforycheskye arkhetypy v russkoy srednevekovoy slovesnosty y poézyy nachala dvadtsatogo veka [Metaphorical archetypes in Russian medieval literature and poetry of the early twentieth century] URL: http://lib.pushkinskijdom.ru/Portals/3/PDF/

TODRL/26_tom/Panchenko_Smirnov/Panchenko_Smirnov.pdf(data zvernennya: 27.05.2019).

14. Sutulina L. H. Etapy doslidzhennya metaforychnykh modeley. Filolohichni nauky [Stages of metaphorical models' studies. Phylological sciences]: [zb. metarialiv pidsumk. nauk. konferentsiyi studentiv ta vykl. fakultetu].Dnipropetrovsk, 2014. S. 403-405.

15. Chudynov A. P. Polytycheskaya lynhvystyka. Nauka [Political linguistics. Science], Moskva, 2006. $256 \mathrm{~s}$

\section{РЕЗЮМЕ}

Ольга Хардикова,

Военно-дипломатическая академия имени Евгения Березняка, г. Киев

\section{Формирование тематических вокабуляров в учебном прцессе з учетом неологизмов и современных тенденций развития анлийского языка}

В статье исследованы способы образования неологизмов в английском языке и обосновано значение языковой компрессии как механизма обогащения английского языка неологизмами, проанализированы особенности формирования лексических неологизмов с помощью языковой компрессии, которую нужно учитывать при проведении занятий в высших военных учебных заведениях. При подготовке статьи был использован комплексный научный анализ проблемы исследования; систематизаџия и обобщение информации, полученной из научных и методических источников; методы сравнения, классификачии, абстрагирования, индукиии и дедукиии. Языковая компрессия и способы ее создания играют важную роль, а также устанавливают новые стандарты для подготовки будущзих спещиалистов, что подразумевает инновации в формировании их навыков владения иностранным языком.

Ключевые слова: языковая компрессия; неологизм; элизия; универбация; лексический аппарат; фразеологизмы.

\section{SUMMARY}

Olga Khardikova, Military Diplomatic Academy named after Yevheniy Berezniak, c. Kyiv

Formation of thematic vocabulary in the educational process considering neologisms and modern trends in the development of the English language

Introduction. Linguistic compression and the ways of its creation plays an important role as well as sets new standarts to future diplomatic staff training, implying innovations in the formation of their foreign language communication skills. According to the new emerging regulations and movement towards meeting NATO standards in assessment of the future specialists and the development of professional communicative skills within a short period of time (two years), the problem of linguistic compression as a tool and means is extremely urgent. Therefore, the 
implementation and further use of the updated Military Diplomatic English withing performance of professional tasks, makes the educational process more differentiated, individualized, focused and interactive.

Purpose. To analyse the tendencies of development of modern English language, the peculiarities of formation of general lexical neologisms by means of language compression.

Methods. Analysis of the researched problem; systematization and generalization of the information obtained from the theoretical sources; methods of comparative analysis, classification, abstraction, induction and deduction.

Results. It has been defined that the use of neologisms withing the framework of linguistic compression when teaching Military Diplomatic English is to facilitate the educational process and is aimed at optimisation of the forms of teaching. The main methodical peculiarities of the linguistic compression are elicited and described in the research. It contributes not only to mastering students' language skills but also to preparing for their future professional activities.

Originality. A concept of linguistic compression within the framework of the formation of neologisms has been introduced as well as the importance of use of neologisms themselves when delievering English in military higher education institutions.

Conclusion. The article defines the essence of the notion "linguistic compression", "neologism", explores the mechanisms of neologism formation in English and identifies the meaning of linguistic compression as a mechanism for enriching English with neologisms, analyzes the peculiarities of formation of common language lexical neologisms using linguistic compression, which should be taken into account when delievering English in higher education institutions.

Key words: Language Compression; Neologism; Elizion; Univerbation; Lexical tool; Phraseologisms. 